\title{
実測に基づく街路樹の植生蒸散モデルに関する研究 THE STUDY ON THE VEGETATION TRANSPIRATION MODELS OF A ROADSIDE TREE BY A FIELD EXPERIMENT
}

\author{
黄 柔 嫚 $^{*}$, 大岡 龍 三** \\ Jouman HUANG and Ryozo OOKA
}

\begin{abstract}
In this study, the details of the existing physiological models of plant transpiration, Jarvis and Kosugi models, were reviewed and field experiments were also conducted to investigate the influence of environmental factors on the transpiration of trees, particularly roadside trees. Data were collected by measuring the environmental factors and the factors influencing stomatal transpiration. The following results were obtained: (1) The transpiration of trees during the daytime was most significantly influenced by solar radiation or photosynthetically active radiation, followed by the leaf or air temperature. (2) The influence of the relative humidity of air on the total amount of transpiration of trees during the daytime was not significant.(3) On the prediction precision of the two models on plant transpiration, Jarvis and Kosugi models were almost the same.
\end{abstract}

Keywords : Environmental factors, Transpiration, Stomatal conductance, Roadside trees, Vegetation transpiration model, Street blocks 環境因子, 蒸散, 気孔コンダクタンス, 街路樹, 植生蒸散モデル, 街区

\section{1. 序}

近年、ヒートアイランド現象による都市熱環境の悪化に対して樹 木は日射遮蔽により地表面の温度上昇を抑制したり、蒸散に伴い日 射熱を地表面や他の固体物体よりもより多く潜熱に変換することに より周囲の空気温度上昇を抑制させる等の熱環境調節機能があるた め、都市熱環境改善効果が期待されている。しかし、一方で蒸散に よる周囲の湿度上昇や樹冠の抵抗による風速低下等によって、屋外 熱環境を悪化させる可能性もあるため、樹木の各熱環境調節機能を 総合的に評価することが必要となる。

コンピュータを用いた数值解析手法による樹木周囲の熱環境評価 は、実測では困難である総合的な検討を可能にするため、コンピュ ータを利用した数值予測手法による樹木の各効果のモデル化に関し て多くの研究が行われている 1)-7)。しかし、その多くは樹木の潜熱 発生に関する蒸散作用として植物の生理特性を殆じ考えておらず、 蒸発効率等のパラメータを変化させるのみで取り扱う場合が多い 1)-5)。

植生からの蒸散は植物生理作用による葉の気孔開度等の影響を強 く受ける。このような植生生理に基づく蒸散モデルを利用すると、 日射量や温度の変化等の環境因子の影響を組み込むことが可能であ り、時間的に変化する環境条件に応じた気孔開度の変化による植生 の実際的な蒸散の変動を考慮することが可能である。農学分野や建 築分野では、生理的な䓏散モデルはいくつか提案されているものの
8)-10)、公園 6)や住宅敷地内 7)に応用したものが主であり、街路樹の蒸 散効果を組み込んだ数值予測を行っている例は少ない。

また、樹木の蒸散量と環境条件に関寸る実測については、成田ら 11)が都市における樹木のオアシス効果に対して野外実験を行ってい る。配置密度の違いによりサザンカの蒸散量には顕著的な差異が現 れるが、このような差異は樹木周囲の環境条件の日射や風との関連 性がみられなかったことを報告している。一方、梅田ら ${ }^{12)}$ は重回帰 分析により環境因子(日射量、気温、絶対湿度、風速)を説明変量に し、ケヤキの蒸散量を目的変量にした重回帰式を算出した。決定係 数は 0.75 以上であり、その重回帰式の有効性を確認した。

したがって、コンピュータを利用した数值予測手法による樹木モ デルの予測精度を向上させ、既成の植生蒸散モデル 8)9)を街区の温熱 数值解析手法に組み込むために、本研究では実測により各環境因子 が樹木、特に街路樹の蒸散量に与える影響を解明し、既存の植物生 理モデルの予測精度を検討する。

\section{2. 検討した植生蒸散モデルの概要}

ここでは代表的な植生蒸散モデルとして Jarvis モデル 8)、小杉モ デル9)を取り上げる。

\section{1 Jarvis モデル ${ }^{8)}$}

植生蒸散モデルで最もよく使われているのは Jarvis モデルであ る。このモデルは 1976 年提案され、蒸散量の計算には Monteith
* 東京大学大学院工学系研究科建築学専攻 大学院生

** 東京大学生産技術研究所 教授・博士 (工学)
Graduate Student, Dept. of Architecture, Faculty of Eng., The Univ. of Tokyo Prof., I.I.S., the Univ. of Tokyo, Dr. Eng. 
により修正された Penman 方程式を用い、飽差や気孔コンダクタン ス、葉面境界層コンダクタンスとともに、葉面に吸収された日射量 等も考慮する因子として含まれている。Jarvis モデルでは電気回路 式のアナロジーより表 1 (2)式に示寸方程式により、蒸散速度 $\mathrm{E}_{\mathrm{j}}$ $\left(\mathrm{mole} / \mathrm{m}^{2}\right.$ ・ s ) を評価している。更に、気孔コンダクタンスの計算に ついては、Jarvis モデルは土壌の水ポテンシャルと大気の二酸化炭 素の濃度の影響も配慮しているが、本研究ではそれらの因子は実験 期間を適してほぼ一定であり、その影響は殆じ無視し得ると考え、

光合成有効放射、温度及び飽差のみが因子として考慮されたモデ ルを検討対象とした( (3)-(6)式に示寸)。

\section{2 小杉モデル ${ }^{9)}$}

小杉のモデルは上に述べた Jarvis モデルを基に飽差に関する関 係式を $\mathrm{S}$ 型曲線に修正したものである( (7)式)。

\section{3. 測定概要}

\section{1 測定期間及び測定場所}

実測は 2009 年 9 月 14 日から 22 日までの 9 日間行った。時間は 午前 9 時から午後 5 時までである。設置場所は周囲の建物の日影に ならないように、東京大学生産技術研究所千葉実験所内の周囲に建 物の少ない、比較的開けた敷地を選定した。

\section{2 測定対象}

測定対象は街路樹で多く使用される常緑広葉樹のシラカシ(図 1 に示す)を選定した。科で蒸散量を計測するために、ポットに植えた シラカシ(高さ $2.4 \mathrm{~m}$ 、樹冠の幅 $0.44 \mathrm{~m}$ ) 測定対象とした(図 2 に示す) 注 1)

\section{3 測定項目}

環境因子には気温、相対湿度、風速、及び光合成有効放射(PAR) がある。蒸散に関する因子には、気孔コンダクタンス、葉面温度、 葉面周囲の湿度、樹木の蒸散量がある。測定項目、サンプル時間、 使用した機器の一覧を表 2 に示し、機器設置の概要を図 3 に示す。

\section{4 測定方法}

\section{4.1 環境因子}

風速は超音波風速計(株式会社ソニック、DA-600 TR61A)を用い サンプリング間隔 $10 \mathrm{~Hz}$ で測定した。気温、相対湿度、全天日射量 については、気象観測ステーション(Grant Instruments(株)、 Mini-Met 03)を用い 5 分毎に測定した。光合成有効日射量(PAR)は 光合成量子センサー(E.M.J(株)、MIJ-14PAR)を用い 5 分毎に測定 した。

\section{4.2 気孔蒸散に関する因子}

気孔蒸散に関する因子はポロメーター(Decagon Devices(株)、 $\mathrm{SC}-1)$ を利用し、1.5M 高さの樹木の各方位の外辺に位置する葉 $\{\mathrm{a}($ 南 面)、b(西面)、c(北面)、d(東面) $\}$ と樹冠内部に位置する葉 $\{\mathrm{e}$ (中心) $\}$ (図 5)を 1 枚ずつ測定サンプルと選定し、30 分毎にそれぞれの気孔 コンダクタンス、葉面温度及び葉面周囲の湿度を測定した。

\section{4.3 樹木の蒸散量}

樹木全体の蒸散量測定は樹木の植えたポットを科の上に載せ、そ の重量を 30 分毎に測定しその減少量を樹木全体の蒸散量とした。

また、土袞からの蒸発と雨の影響を最低限にするためにポットの 上に防水素材を設置し、樹木やポットの隙間も接着剤や粘着テープ で密着させた(図 4(b)に示す)。

\section{4.4 葉面積}

葉面積は測定対象より 100 枚の葉をサンプルとしてそれぞれの写 真を撮り(図 6 に示す)、画素面積を算出できるソフトウェアを利用 し個々の葉の面積を求めた。それらの平均值を求めて樹木の全葉枚 数に掛け合わせ全葉面積とした。

\section{4. 実測結果と考察}

\section{1 実測期間中の気象状況}

表 1 各モデルの内容の一覧

\begin{tabular}{l}
\hline Jarvis と小杉モデル 8)9) \\
\hline $\mathrm{E}=18 \times \mathrm{E}_{\mathrm{j}}$ \\
$\mathrm{E}_{\mathrm{j}}=\frac{\left(\mathrm{g}_{\mathrm{s}} \times \mathrm{ga}_{\mathrm{a}}\right)}{\left(\mathrm{g}_{\mathrm{s}}+\mathrm{g}_{\mathrm{a}}\right)}\left(\mathrm{W}_{\mathrm{i}}-\mathrm{W}_{\mathrm{a}}\right)$ \\
$\mathrm{g}_{\mathrm{s}}=\mathrm{g}_{\mathrm{smax}} \times \mathrm{f}_{\mathrm{Q}}(\mathrm{Q}) \times \mathrm{f}_{\mathrm{T}}\left(\mathrm{T}_{\mathrm{a}}\right) \times \mathrm{f}_{\mathrm{D}}(\mathrm{D})$ \\
$\mathrm{f}_{\mathrm{Q}}(\mathrm{Q})=\frac{\mathrm{Q}}{\mathrm{Q}+\left(\frac{\left(\mathrm{ssmax}_{\mathrm{a}}\right.}{\mathrm{a}}\right)}$ \\
$\mathrm{f}_{\mathrm{T}}\left(\mathrm{T}_{\mathrm{a}}\right)=\left(\frac{\mathrm{Ta}-\mathrm{Tl}}{\mathrm{To}-\mathrm{Tl}}\right)\left\{\left(\frac{\mathrm{Th}-\mathrm{Ta}}{\mathrm{Th}-\mathrm{To}}\right)^{\left(\frac{\mathrm{Th}-\mathrm{To}}{\mathrm{T} 0-\mathrm{Tl}}\right)}\right\}$ \\
$\mathrm{f}_{\mathrm{D}}(\mathrm{D})=1-\mathrm{b}_{1} \times \mathrm{D}$ \\
$\mathrm{f}_{\mathrm{D}}(\mathrm{D})=\frac{1}{1+\left(\frac{\mathrm{D}}{\mathrm{b} 1}\right)^{\mathrm{b}}}$
\end{tabular}

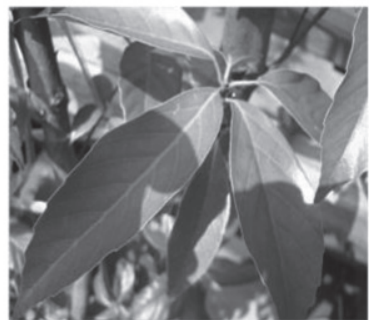

図 1 測定対象シラカシ

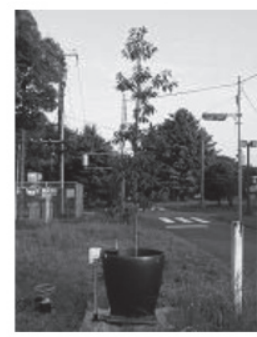

図 2 樹木設置状況
表 2 測定項目一覧

\begin{tabular}{|c|c|c|c|c|c|}
\hline \multicolumn{3}{|c|}{ 測定項目（機器の精度） } & サンプ & 設置 & 測定機器 \\
\hline \multirow{4}{*}{$\begin{array}{l}\text { 囂 } \\
\text { 境 } \\
\text { 区 }\end{array}$} & 1 & 温湿度 $\left( \pm 0.4^{\circ} \mathrm{C} 、 \pm 2 \%\right)$ & 5分 & \multirow[t]{3}{*}{$1.5 \mathrm{M}$} & \multirow{3}{*}{$\begin{array}{l}\text { 超音波風速 } \\
\text { 計(A)、気象 } \\
\text { 観測ステー } \\
\text { ション(B) }\end{array}$} \\
\hline & 2 & 風速（ $\pm 1 \% ）$ & 0.1 秒 & & \\
\hline & 3 & 全天日射量（ $( \pm 3 \% ）$ & 5分 & & \\
\hline & 4 & $\operatorname{PAR}( \pm 3 \%)$ & 5分 & $1.5 \mathrm{M}$ & $\begin{array}{l}\text { PAR センサ } \\
\text { ー(C) }\end{array}$ \\
\hline \multirow{4}{*}{$\begin{array}{l}\text { 気 } \\
\text { 孔 }\end{array}$} & 5 & $\begin{array}{l}\text { 気孔コンダクタンス } \\
( \pm 10 \%)\end{array}$ & 30 分 & & \multirow{3}{*}{$\begin{array}{l}\text { ポロメータ } \\
\text { ー }\end{array}$} \\
\hline & 6 & 葉面温度（-） & 30分 & & \\
\hline & 7 & 葉面周囲湿度 (-) & 30分 & & \\
\hline & 8 & 樹木蒸散量（ $( \pm 10 \mathrm{~g} ）$ & 30分 & $1.5 \mathrm{M}$ & 電子秤(D) \\
\hline
\end{tabular}

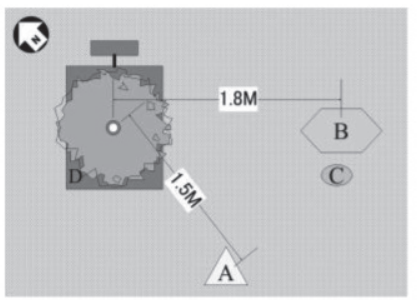

(a) 設置の位置

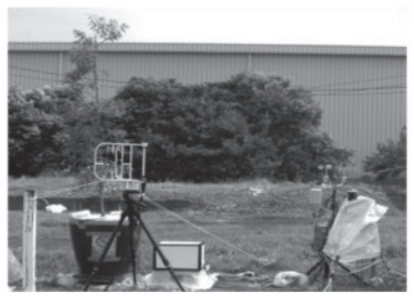

(b) 設置の風景
図 3 機器設置の概要 
実測期間中の気象状況を表 3 に示す。実測期間中は晴天 5 日間、 曇天 4 日間であった。

\section{2 環境因子間の関係}

\section{2. 1 全天空放射と PAR の関係}

PAR は植物の光合成作用に有効な日射量でありこの波長の範囲 は 400-700nm であり、全天空放射とは線形関係がある。図 7(a)に 示すように結果は理論と一致し相関係数も 0.994 であり非常に顕著 な線形関係が見られる。

\section{2.2 気温と葉温の関係}

測定期間中の気温と葉温の日平均值の変化を図 7(b)に示す。葉温 は気温より高くその差が $2-4^{\circ} \mathrm{C}$ 程度であると見られた。これらの測 定結果は、既往の文献 13) とも一致する。

\section{2. 3 PAR と葉温の関係}

$\mathrm{PAR}$ と葉温の関係は図 7(c)に示すように PAR の増加につれ葉温 も増加し、相関係数も 0.853 であり線形関係が顕著となった。

\section{2.4 葉温と飽差の関係}

葉温と飽差の関係については図 7(d)に示すように葉温の増加につ れ飽差も増加し、相関係数も 0.900 であり非常に強い線形関係が見 られる。ここで飽差(VPD、Vapor Pressure Difference)は表 1 式(2) 中の Wi-Wa を表わし、水蒸気分圧 $[\mathrm{mb} / \mathrm{mb}$ を単位として表した。

\section{3 環境因子と蒸散量の関係}

$\mathrm{X}-\mathrm{Y}$ 分布図と回帰分析を用い日蒸散量と各環境因子の日平均值をそ れぞれ比較しそれらの関係を分析した。

\section{3.1 蒸散作用の基礎式}

蒸散とは気孔により植物内の水蒸気が外に散逸する過程である。 その原理は図 8 に示寸ように電気回路の法則と似ており、外と植物 内における水蒸気量の差、寸なわち飽差に比例し、気孔内から外一 の輸送経路における抵抗に反比例する。この輸送経路における抵抗 は気孔抵抗と葉面境界層抵抗であり、蒸散速度は式(8)になる。

$$
E_{j}=\frac{W_{i}-W_{a}}{\left(r_{a}+r_{s}\right)}
$$

これより、植物生理特性である気孔開度は気孔抵抗の逆数である 気孔コンダクタンスで表現でき蒸散速度は式(9)に変換できる。

$$
E_{j}=\frac{W_{i}-W_{a}}{\left(\frac{1}{g a}+\frac{1}{g_{s}}\right)}
$$

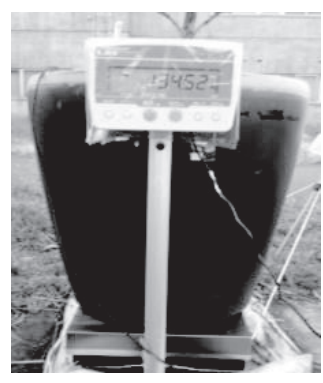

(a) 蒸散量測定状況

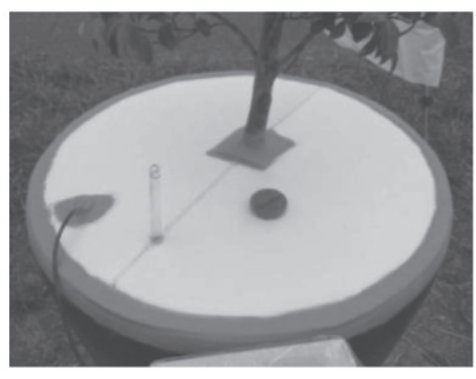

(b) 防水施設
図 4 樹木の蒸散量を測るための設置

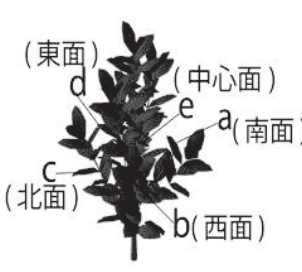

図 5 ポロメータで測定 した葉の位置

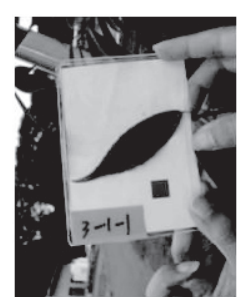

図 6 撮った葉の 写真例

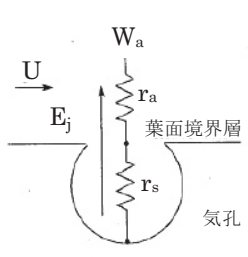

$\mathrm{W}_{\mathrm{i}}$ 原理 19)

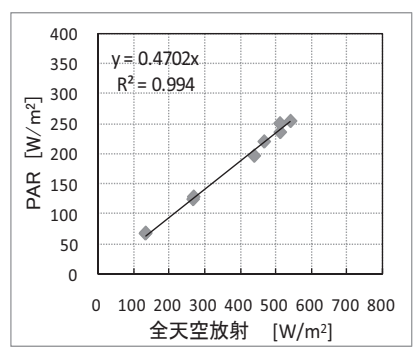

（a）全天空放射と PAR の関係

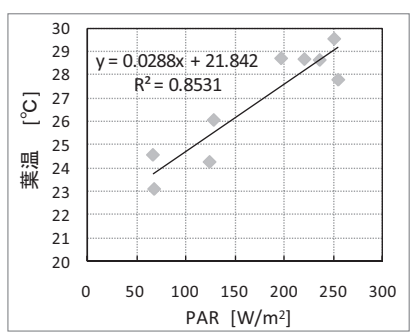

(c) PAR と葉温の関係

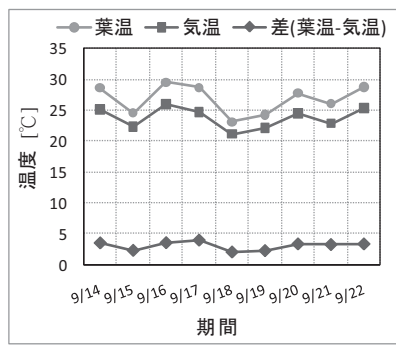

(b) 気温と葉温の関係

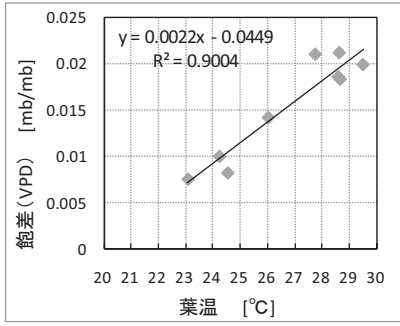

（d）葉温と飽差の関係

図 7 各環境因子の間の関係

表 3 実測期間中の気象状況一覧（表示数值は 9:00-17：00の平均值）

\begin{tabular}{l|c|c|c|c|c|c|c|c|c|c|c}
\hline \multicolumn{2}{c}{ 各環境因子 } & $9 / 14$ & $9 / 15$ & $9 / 16$ & $9 / 17$ & $9 / 18$ & $9 / 19$ & $9 / 20$ & $9 / 21$ & $9 / 22$ & $\begin{array}{c}\text { 全期間 } \\
\text { 平均 }\end{array}$ \\
\hline 全天空放射 & $\mathrm{W} / \mathrm{m}^{2}$ & 513 & 133 & 512 & 468 & 134 & 267 & 542 & 269 & 440 & 364 \\
\hline $\mathrm{PAR}$ & $\mathrm{W} / \mathrm{m}^{2}$ & 236 & 67 & 251 & 221 & 68 & 125 & 255 & 129 & 197 & 172 \\
\hline 葉温 & ${ }^{\circ} \mathrm{C}$ & 28.6 & 24.5 & 29.5 & 28.6 & 23.1 & 24.2 & 27.8 & 26.0 & 28.7 & 26.8 \\
\hline 気温 & ${ }^{\circ} \mathrm{C}$ & 25.1 & 22.3 & 26.0 & 24.7 & 21.1 & 22.1 & 24.5 & 22.8 & 25.4 & 23.8 \\
\hline 相対湿度 & $\%$ & 71.3 & 73.5 & 73.9 & 71.1 & 71.3 & 72.1 & 67.9 & 68.5 & 66.7 & 70.7 \\
\hline 飽差 & $\mathrm{mb} / \mathrm{mb}$ & 0.019 & 0.008 & 0.020 & 0.021 & 0.007 & 0.010 & 0.021 & 0.014 & 0.018 & 0.015 \\
\hline 風速 & $\mathrm{m} / \mathrm{s}$ & 1.12 & 0.74 & 1.10 & 1.13 & 1.22 & 1.40 & 1.40 & 0.80 & 0.91 & 1.10 \\
\hline
\end{tabular}




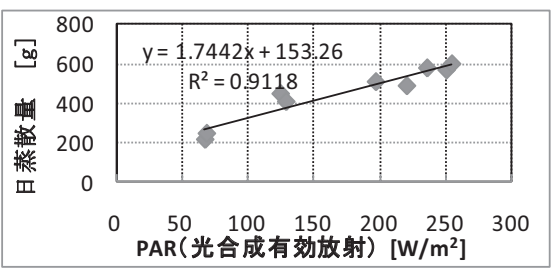

図 9 (a) PAR と日蒸散量の関係

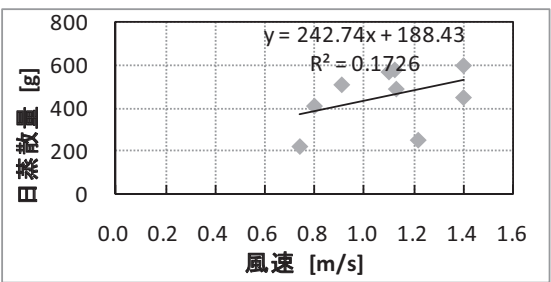

図 10 (a) 風速と日蒸散量の関係

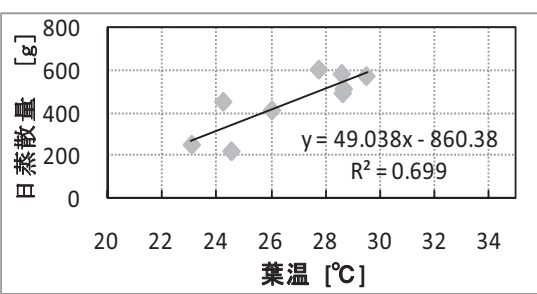

図 11 (a) 葉温と日蒸散量の関係

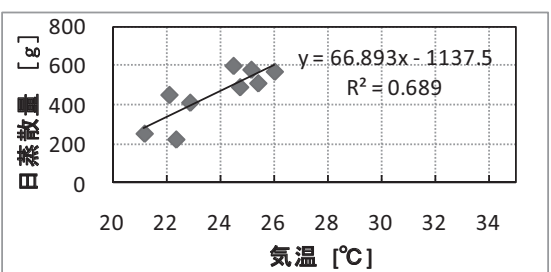

図 12 (a) 気温と日蒸散量の関係

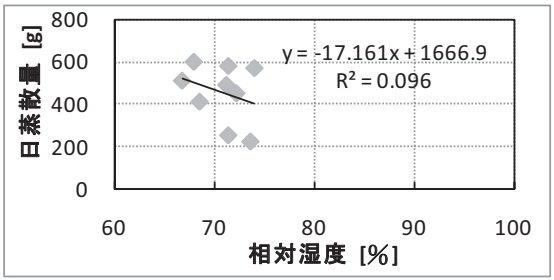

図 13 (a) 相対湿度と日蒸散量の関係

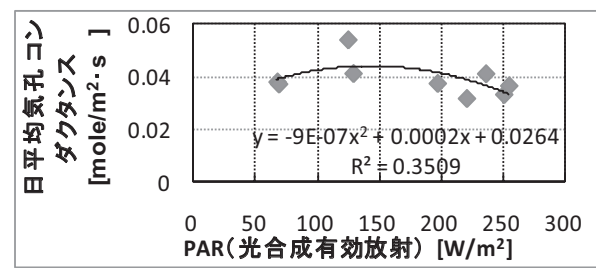

図 9 (b) PAR と気孔コンダクタンスの関係

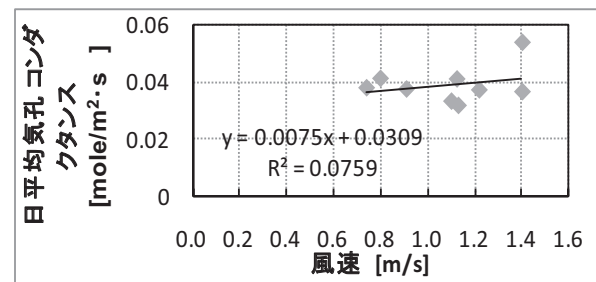

図 10 (b) 風速と気孔コンダクタンスの関係

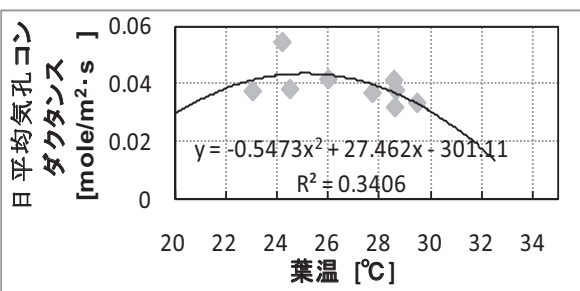

図 11 (b) 葉温と気孔コンダクタンスの関係

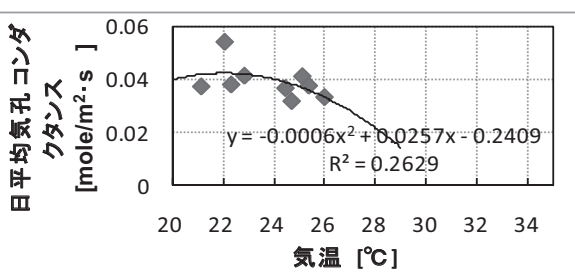

図 12 (b) 気温と気孔コンダクタンスの関係

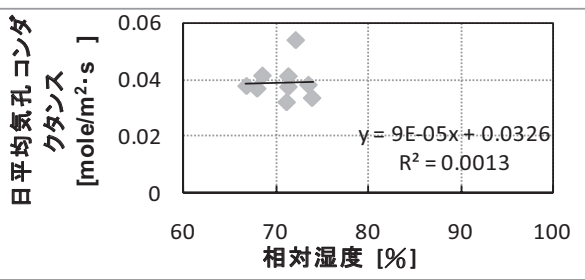

図 13 (b) 相対湿度と気孔コンダクタンスの関係

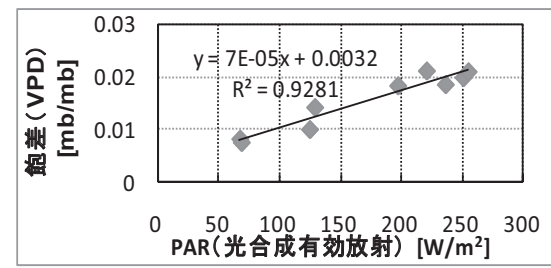

図 9 (c) PAR と飽差の関係

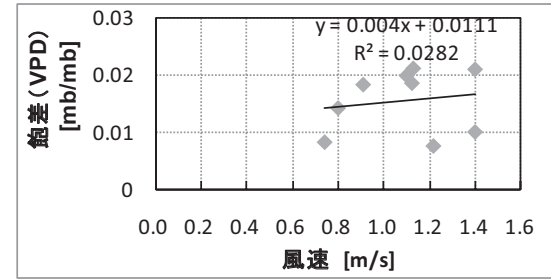

図 10 (c) 風速と飽差の関係

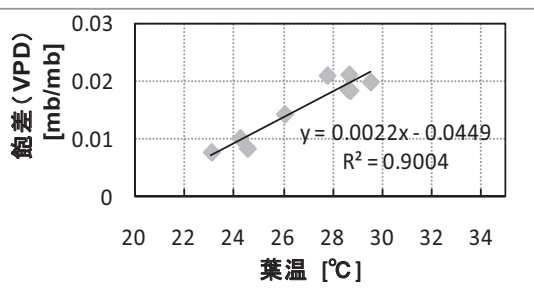

図 11 (c) 葉温と飽差の関係

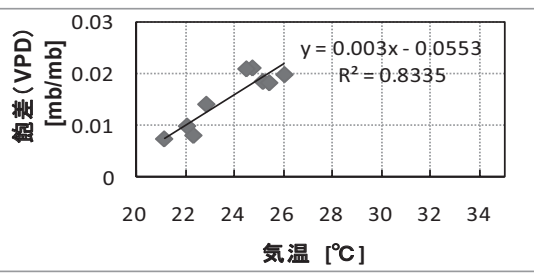

図 12 (c) 気温と飽差の関係

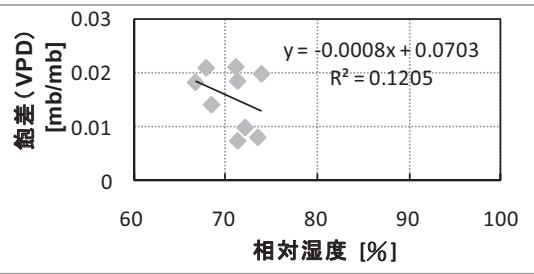

図 13 (c) 相対湿度と飽差の関係

\section{3. $2 \operatorname{PAR}$ (光合成有効放射) との関係}

蒸散量と PAR の関係は図 9(a) に示すように、PAR の増加と共に 増加する傾向が見られ、決定係数も 0.922 であり、正の相関は非常 に高い。

主な原因は葉が日射を受け光合成作用によって気孔を開放したと 考える。しかし、図 9(b) に示すように日射が気孔に与える影響は、 式(15)に示すように蒸散量は気孔開度に影響を受けるだけでなく飽 差の影響もある。PAR と飽差の関係図 9(c)が示すように、PAR の増 加とともに飽差も増加し、それにより蒸散量も増加したものと考え られる。

\section{3.3 風速との関係}

図 10(a) に示すように蒸散量は風速の増加と共に増加する傾向が 見られたが、決定係数は僅か 0.173 と小さい。

葉面境界層の理論により、樹木の周囲の風速が増加すると葉面付
近の境界層の厚さは薄くなり、境界層抵抗が小さくなるため、蒸散 量は増加する。また風速が増加するに従い、気孔を閉じ気孔コンダ クタンスが低下寸ることが予想されたが、実際には風速が気孔開度 や飽差に与える影響も小さい(図 10(b)、図 10(c))。

\section{3.4 葉温及び気温との関係}

葉温については図 11(a) に示すように葉温の増加により蒸散量も 増加した。決定係数は 0.699 であり比較的高い。

植物生理により、温度が上昇すると光合成作用に参与する酵素の 活性を促進させ、間接的に気孔を広げるが、図 11(b) に示すように 葉温と気孔の関係にはある最大值に達すると減少する傾向もある。 しかし、葉温の増加による飽差の上昇効果が強いために(図 11(c))、 蒸散量は葉温の上昇に伴い増加寸るという傾向が見られた。気温に ついても葉温とほぼ同じ結果が見られ、原因も同じと考えられる(図 $12(\mathrm{a})-12(\mathrm{c}))$ 。 


\subsection{5 相対湿度との関係}

蒸散量と相対湿度の関係は図 13(a) に示すように、相対湿度の増 加につれ蒸散量はやや減少する傾向が見られた。しかし決定係数は 0.096 であり、この傾向は非常に弱い。

考えられる原因は空気中の相対湿度が増加すると、水蒸気量が増 え(同温度の条件で)、葉の中における水蒸気量との差、寸なわち飽 差は減少し蒸散量も減少する(式(9))。しかしその効果は弱い(図 13(c))ため、この減少傾向も小さいと考えられる。

\section{5 各蒸散モデルの予測精度の検討}

第 2 章に述べた植生蒸散モデルの予測精度の検討については二つ の段階に分けて検討した。一つめは各モデルにおけるパラメータを 同定する。次に、日積蒸散量の推定と予測精度を検討する。

\section{1 各モデルのパラメータの同定結果}

Jarvis と小杉モデルにおけるパラメータの同定は 9/14-22 日の間 に、実測より得た気孔コンダクタンスと環境因子の值を用い非線形 回帰最小二乗分析を行い、最適值を決定した。既往研究 9) 参考に して Tl は $5{ }^{\circ} \mathrm{C}$ と固定し、Th は 45 から $50^{\circ} \mathrm{C}$ 範囲で最適值を同定 した。なお、初期值は小杉より同定されたアラカシの值（表 4）を 参考として、モデルの適合度を表す指標は $\mathrm{R}^{2}$ を用いた。

同定した結果は表 4 に示すように、小杉の $\mathrm{R}^{2}$ は $45 \%$ となり Jarvis の $42 \%$ よ高いことが見られる。このため全期間のデータに対して 飽差関係式を $\mathrm{S}$ 型曲線に修正した小杉モデルは確かにわずかである が gsに対しての予測精度を向上した。

更に、同定して得たパラメータを(3)-(7)式に代入し、各日の gs を 求め、日毎に各モデルの推定值と実測值の比較を図 14 に示寸。平 均的に言うと推定値は実測值とほぼ一致し、Jarvis と小杉による推 定值は全期間の平均で $0.0388,0.0390 \mathrm{~mole} / \mathrm{m}^{2} \mathrm{~s}$ となり、実測值の $0.0391 \mathrm{~mole} / \mathrm{m}^{2} \cdot \mathrm{s}$ との差は $0.0003 \mathrm{~mole} / \mathrm{m}^{2} \cdot \mathrm{s}$ 以下であった。測定期 間中の変動を見ると、実測值に比べて両モデルともその変動は小さ い。このことは両モデルの環境因子に対する変動の振幅が小さいこ とが推測される。

\section{2 各蒸散モデルによる積蒸散量の予測精度の検討}

Jarvis と小杉モデルによる日積蒸散量の推定については 5.1 節で

表 4 Jarvis と小杉モデルの同定した結果

\begin{tabular}{c|c|c|c|c|c|c|c|c|c}
\hline \multicolumn{2}{c|}{} & $\mathrm{g}_{\text {smax }}$ & $\mathrm{a}$ & $\mathrm{b}_{1}$ & $\mathrm{~b}_{2}$ & $\mathrm{~T}_{1}$ & $\mathrm{~T}_{\mathrm{o}}$ & $\mathrm{T}_{\mathrm{h}}$ & $\mathrm{R}^{2}$ \\
\hline \multirow{2}{*}{ Jarvis } & 初期值 & 0.1 & 0.00479 & 0.122 & - & - & 44 & 45 & - \\
\cline { 2 - 10 } & 同定值 & 0.091 & 0.00171 & 0.248 & - & 5.0 & 36.4 & 50.0 & 0.42 \\
\hline \multirow{2}{*}{ 小杉 } & 初期值 & 0.45 & 0.0045 & 4.58 & 4.1 & - & 44 & 45 & - \\
\cline { 2 - 10 } & 同定值 & 0.099 & 0.00203 & 2.23 & 2.86 & 5.0 & 41.9 & 46.3 & 0.45 \\
\hline
\end{tabular}

同定して得たパラメータを代入し、式(1)—(7)を用い各変数の 30 分 毎で測定した值を代入し、葉面境界層コンダクタンスは定数(1.13 $\mathrm{mole} / \mathrm{m}^{2} \cdot \mathrm{s}$ ) で仮定し計算を行った。次に、求めた蒸散速度に 30 分の 時間間隔と実測より得たシラカシの葉面積 $1.87 \mathrm{~m}^{2}$ をかけ、30 分毎 の積蒸散量を求めた。最後に朝 9 時から午後 5 時までの量を合計し た。

二つのモデルの推定結果を図 15 に示す。Jarvis と小杉モデルと も平均的に実測值より大きくなる傾向が見られたが、全体的な変動 傾向は実測值とほぼ一致している。また Jarvis と小杉モデルの結果 は殆ど一致しており、各日の平均誤差の絶対值は Jarvis と小杉の方 は両者とも $25 \%$ である。

\section{3 ga の蒸散量に対する影響についての考察}

今回、日積算蒸散量の予測において、蒸散モデルと実測值に差が 生じたことにいくつかの原因が考えられる。各蒸散モデルは実測さ れた気孔コンダクタンスを元にモデル定数の同定をしているため、 前節で示したように平均的には推定值と実測值は一致する。したが って、実測された蒸散量と推定された蒸散量の不一致については、 測定された蒸散量と気孔コンダクタンスの測定精度の問題も要因の 一つと考えられる。それ以外にも葉面境界層コンダクタンスのモデ ル化についての問題も考えられうる。 $\mathrm{g}$ 怔一般に 0.4 から 3.2 $\mathrm{mole} / \mathrm{m}^{2} \cdot \mathrm{s}$ までの範囲 ${ }^{14) 15}$ 15) と言われており、前節で利用した ga の $1.13 \mathrm{~mole} / \mathrm{m}^{2} \cdot \mathrm{s}$ という值はその中で更に一般的な数值を採用し

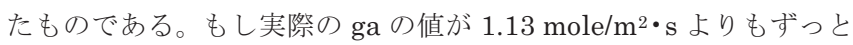
小さいとすれば、境界層抵抗が大きくなり推定された蒸散量は実測 のそれに近くなることになる。例えば Meinzer ら 17)によれば、 Anacardium excelsum に対して gaは 0.3〜 $0.4 \mathrm{~mole} / \mathrm{m}^{2} ・ \mathrm{~s}$ 程度であ るという報告もある。

そこで $\mathrm{g}_{\mathrm{a}}$ に対し表 5 に示寸既存の三つモデル 6)18)19) $\mathrm{g}_{\mathrm{a}} \mathrm{A}$ 、 $\mathrm{g}_{\mathrm{a} \_\mathrm{B}}$ と $\mathrm{g}_{\mathrm{a}_{-}} \mathrm{C}$ モデルに対して検討した。その結果を図 16 に示す。推定 した蒸散量の結果はほぼ一致し、各モデル間の差はほとんどないこ とが確認された。 $g_{a} \_A 、 g_{a} B$ と $g_{a}$ C モデルにより推定した $g_{a}$ は 平均でそれぞれ、2.63、1.04、1.94 $\mathrm{mole} / \mathrm{m}^{2} ・ \mathrm{~s}$ であり、既存のモデ ルでは期待したような小さな $\mathrm{g}_{\mathrm{a}}$ の值は得られなかった。

\section{6. 結論}

夏季における実測により、各種環境因 子が樹木の蒸散量に与える影響について 分析を行い Jarvis 及び小杉の植物生理 モデルの予測精度を検討した。

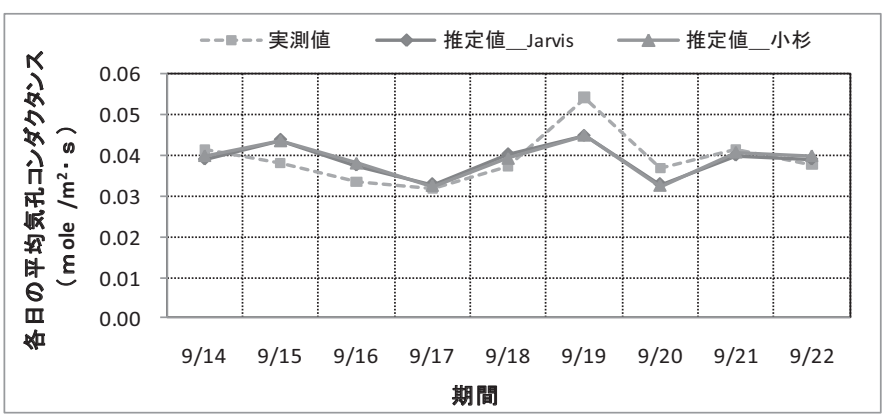

図 14 gs の Jarvis と小杉モデルによる推定值と実測值の比較

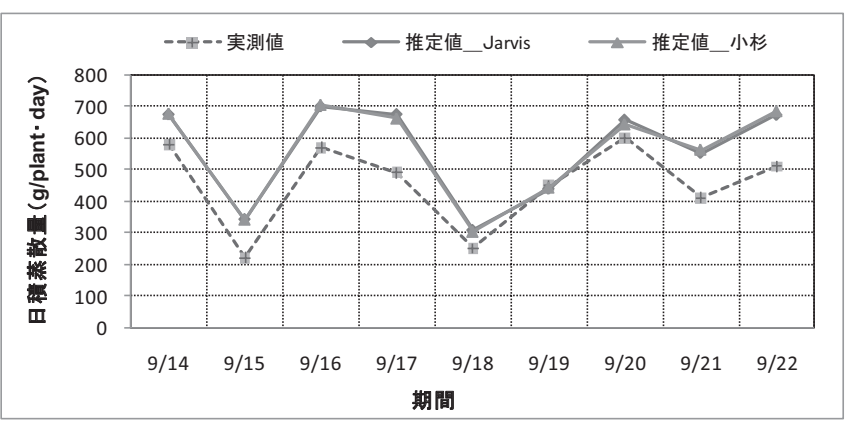

図 15 日積蒸散量の二つのモデルによる推定值と実測值の比較 
実測期間の各環境因子の間の関係を分析すると、ある環境因子の 間に強い関係があることが分かった。PAR は全天空放射量及び葉温 と強い線形関係があり、葉温の方は飽差に与える影響も強く線型増 加の関係があった。気温と葉温の関係は昼に葉温は気温より高くそ れらの差は $2-4{ }^{\circ} \mathrm{C}$ であった。

実測期間の環境因子と蒸散量の関係を分析すると、実測より測定 した環境因子の中で日蒸散量に最も影響を与えたものは PAR(光合 成有効放射)で、その次に温度であったが、相対湿度は日蒸散量に与 える影響が殆ど見られなかった。

日積蒸散量に対する予測精度を検討した結果は Jarvis と小杉の モデルとも実測した蒸散量より若干大きめの值を示し、両者の結果 は殆ど一致している結果となった。

次に、Jarvis と小杉モデルに対する検討について、既往研究で提 案された葉面境界層コンダクタンスモデルを組み込んで検討すると、 推定した蒸散量の結果はほぼ一致し、これらのモデル間の差異は得 られなかった。

表 5 gaに関するモデル詳細の一覧

\begin{tabular}{l|ll}
\hline \multicolumn{1}{c|}{ モデル } & \multicolumn{2}{c}{ 方程式 } \\
\hline $\mathrm{g}_{\mathrm{a} \_\mathrm{A}^{6)}}$ & $=\mathrm{ch} \times \mathrm{u}$ & $(10)$ \\
\hline $\mathrm{g}_{\mathrm{a} \_\mathrm{B}^{18)}}$ & $=0.147 \times \sqrt{\frac{\mathrm{u}}{\mathrm{d}}}$ \\
\hline $\mathrm{g}_{\mathrm{a} \_\mathrm{C}^{19)}}$ & $=\rho \times \mathrm{k} \times \frac{\mathrm{u}^{0.55}}{\mathrm{~W}^{0.2} \times \mathrm{L}^{0.35}}$ \\
\hline
\end{tabular}

表 6 ga に関するモデルにおける変数の設定

\begin{tabular}{c|cr}
\hline \multicolumn{3}{|c}{ ga に関するモデルにおける変数の設定值 } \\
\hline $\mathrm{W}_{\max }$ & 0.03 & {$[\mathrm{~m}]$} \\
\hline$\rho$ & 1.293 & {$\left[\mathrm{~kg} / \mathrm{m}^{3}\right]$} \\
\hline $\mathrm{k}$ & $5.55 \times 10^{-3}$ & {$[-]$} \\
\hline $\mathrm{W}$ & 0.025 & {$[\mathrm{~m}]$} \\
\hline $\mathrm{L}$ & 0.1 & {$[\mathrm{~m}]$} \\
\hline
\end{tabular}

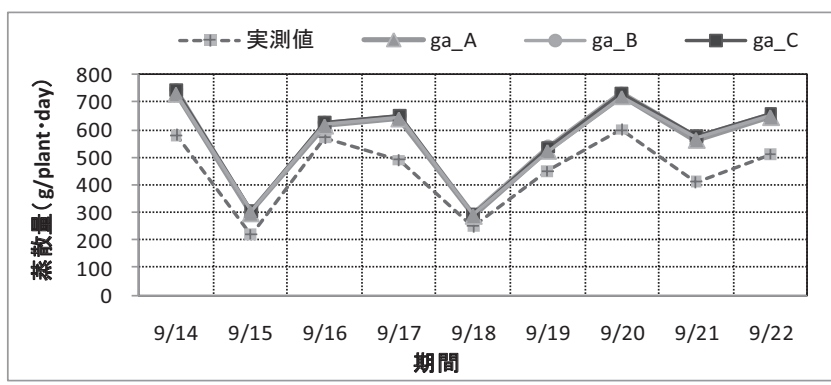

図 16 ga に関するモデルを組み込んだ蒸散量推定値と実測值の 比較

\section{謝辞}

本研究の遂行にあたり、東京大学大学院農学研究科 鈴木雅一教 授より植物蒸散量測定に関し、有益な御助言をいただいた。ここに 記して深甚なる謝意を表します。

注

注 1）本報では、今回の一本樹木の実測結果から、シラカシの定量的かつ一 般的な特性が得られることは困難であるとは考えている。しかしながら、 シラカシの環境因子に対する定性的な応答はある程度把握できると考え、 また既往の測定結果 2021$)$ とも類似した值を得たため、それなりに信頼でき るデータであると判断した。更に、今後シラカシの一般的な特性を同定す るために、このようなデータ蓄積を行う上での事例の一部としての価值は
十分にあるものと考えている。今回使用した樹木は蒸散量を測定するため の栎の制限上、成年木を利用することはできず幼木を対象としました。幼 木を利用することによる主な影響は gs の測定值に与えると考えられるが、 久野 20) と近藤 21)の研究による測定した成年のシラカシの gs 平均值は 0.03-0.05 mole $/ \mathrm{m}^{2} \cdot \mathrm{s}$ であり、今度の実測值とはほぼ一致になっており、あ る程度信頼できると判断した。

\section{本論文に関する既発表論文}

a) 黄柔嫚, 大岡龍三 : 環境因子が街路樹の蒸散量に与える影響の実測, 日 本建築学会関東支部研究報告集 II(環境工学)，80，pp.189-192，2010.3

b) 渡辺晃, 黄柔嫚, 大岡龍三 : 植生蒸散モデルの屋外温熱環境解析手法一 の組み込みに関する研究 その 1 一環境因子が街路樹の蒸散量に与える 影響の実測, 日本建築学会大会学術講演梗概集, D-1, pp.883-884, 2010.9

c) 黄柔嫚, 大岡龍三 : 植生蒸散モデルの屋外温熱環境解析手法への組み込 みに関する研究 その 2-Jarvis、小杉及び神田の植生蒸散モデルの予 測精度に関する検討, 日本建築学会大会学術講演梗概集, D-1, pp.885-886, 20010.9

\section{参考文献}

1）吉田伸治, 連成数值解析による屋外温熱環境の評価と最適設計法に関す る研究, 東京大学博士論文, 2001.3

2）平岡久司，丸山敬，中村泰人，桂順治：植物群落内および都市キャノピー 内の乱流モデルに関する研究(その1)乱流モデルの作成, 日本建築学会計 画系論文報告集，406，pp.1-9, 1989.12

3）吉田伸治, 大岡龍三，持田灯：樹木モデルを組み込んだ対流・放射・湿 気輸送連成解析による樹木の屋外温熱環境緩和効果の検討, 日本建築学 会計画系論文集，536, pp.87-94, 2000.8

4）佐々木澄, 岩田達明, 持田灯, 渡辺浩文, 吉野博: 街路樹がストリート キャニオン内の温熱空気環境に及ぼす影響に関する数值解析，日本建築 学会環境系論文集，605，pp.139-146, 2006.7

5）坂本雄三，小島悦史，足永靖信，今野雅：CFD を利用した樹木のクール スポット効果の数值解析 その 1 樹木における放射と蒸散に関寸る計 算モデル, 日本建築学会大会学術講演梗概集, D-1, pp.689-690, 2005.9

6）神田学, 森脇 亮, 横山 仁: 明治神宫の森の気候緩和機能・大気浄化機能 の評価：(2) 森林環境気象モデルによるシミュレーション, 天気 44,10 , pp.713-731, 1997.10

7）佐藤愛，吉田治典，伊藤麻美子，村上大輔：温熱環境改善のための樹木 の蒸散作用モデルに関する基礎的研究, 日本建築学会近畿支部研究報告 集（環境系），44，pp.393-396, 2004.6

8) Jarvis, P.J.: The interpretation of the variation in leaf water potential and stomatal conductance in canopies in the field, Phil. Trans. R. Soc. Lond., 273, pp.593-610, 1976

9）小杉緑子, 小橋澄治, 柴田昌三: 数種常緑広葉樹における気孔コンダク タンスのモデル化，日本緑化工学会誌， 20，3，pp.158-167, 1995

10）神田学, 日野幹雄：大気-植生-土壤モデルによる数值シミュレーション その 1 植生効果のモデリ, 水文·水資源学会誌，3，3， pp.37-46, 1990

11）成田健一，萩島理，谷本潤，高野武将：都市域における樹木の蒸散特性一 オアシス効果に関する野外実験，日本建築学会環境系論文集， 608 , pp.59-66, 2006.10

12）梅田和彦，深尾仁，田村明宏：熱環境の評価における樹木の夏蒸散量に 関する基䃈的検討，日本建築学会環境系論文集， 601，pp.15-20, 2006.3

13）荻島理，片山忠久，林徽夫，谷本潤：樹木の放射温度分布に関する実測 その 1 一街路樹のある街路の温熱環境予測, 日本建築学会計画系論文集, 516 , pp.79-85, 1999.2

14） Larcher, L.(佐伯敏郎·館野正樹 監訳)：植物生態生理学(第 2 版)，シュプ リンガー・フェアラーク東京株式会社，p.176, 2004

15) Robers, J., O.M.R. Cabral and L.F. DeAguiar.stomatal and boundary-layer conductatance in an Amazonian Terra firme rain forest, J. Appl. Ecol., 27, pp336-353,1990.

16) Martin, T. A., Hinckley, T. M., Meinzer, F. C., Sprugel, D. G.:Boundary layer conductance, leaf temperature and transpiration of Abies amabilis branches, Tree Physiol., 19(7), pp435-443, 1999.

17) Meinzer, F. C., G. Goldstein, N.M. Holbrook, P. Jackson and J. Cavelier.: Stomatal and environmental control of transpiration in a lowland tropical forest tree, Plant Cell Environ., 16, pp429-436, 1993.

18）Campbell, G.S., Norman, J.M. : 生物環境物理学の基礎（第 2 版）, 森 
北出版, p.113, 2003

19）坂本雄三, 壽浦光晴, 工藤善 : 都市緑化植物としての常緑低木植栽から の蒸散量に関する研究 その 1 一蒸散量推定モデルと造園パターンに関 するケーススタディ, 日本建築学会大会学術講演梗概集, D-1, pp.283-286, 2001.9
20）久野春子, 新井一司: 温度 - 湿度条件が 5 樹種の純光合成・蒸散速度 気孔コンダクタンスにおよぼす影響, 日本緑工学会誌, $28,1, \mathrm{pp} .20-25$, 2002

21）近藤隆之, 神保高之, 大西勝典 : 樹木の大気污染物質吸収能力の個体差 と季節変化, 富山県環境科学センタ-年報研究報告, 31, 2, pp.9-13, 2003

附表 1 : 記号

$\mathrm{E}:$ 蒸散速度 $\left[\mathrm{g} / \mathrm{m}^{2} \cdot \mathrm{s}\right] \quad \mathrm{E}_{\mathrm{j}}$ : 蒸散速度 $\left[\mathrm{mole} / \mathrm{m}^{2} \cdot \mathrm{s}\right] \quad \mathrm{W}_{\mathrm{i}}$ : 葉面上での飽和水蒸気分圧 $[\mathrm{mb} / \mathrm{mb}] \quad \mathrm{W}_{\mathrm{a}}$ : 大気の水蒸気分圧 $[\mathrm{mb} / \mathrm{mb}] \quad \mathrm{g}_{\mathrm{s}}:$ 気孔コ ンダクタンス $\left[\mathrm{mole} / \mathrm{m}^{2} \cdot \mathrm{s}\right] \quad \mathrm{g}_{\mathrm{a}}$ ：葉面境界層コンダクタンス $\left[\mathrm{mole} / \mathrm{m}^{2} \cdot \mathrm{s}\right] \quad \mathrm{g}_{\mathrm{smax}}$ : 最大気孔コンダクタンス $\left[\mathrm{mole} / \mathrm{m}^{2} \cdot \mathrm{s}\right] \quad \mathrm{Q}:$ 光合成有効放射 $\left[\mu \mathrm{mole} / \mathrm{m}^{2} \cdot \mathrm{s}\right] \quad \mathrm{T}_{\mathrm{a}}$ : 気温 $\left[{ }^{\circ} \mathrm{C}\right] \quad \mathrm{D}$ : 飽差 $[\mathrm{kPa}] \quad \mathrm{To}$ : 最適温度 $\left[{ }^{\circ} \mathrm{C}\right] \quad \mathrm{Tl}$ : 最低限界温度 $\left[{ }^{\circ} \mathrm{C}\right] \quad \mathrm{Th}$ : 最高限界温度 $\left[{ }^{\circ} \mathrm{C}\right] \quad \mathrm{a}:$ 光によって気孔が 開く反応の効率[-] $\quad \mathrm{b}_{1}$ : 気孔コンダクタンスが $1 / 2$ になる飽差の值 $[\mathrm{kPa}] \quad \mathrm{b}_{2}$ : 曲率[-] $\quad \mathrm{r}_{\mathrm{a}}$ : 葉面境界層抵抗 $\left[\mathrm{m}^{2} \cdot \mathrm{s} / \mathrm{mole}^{\mathrm{N}}\right] \quad \mathrm{r}_{\mathrm{s}}$ : 気玌抵抗 $\left[\mathrm{m}^{2}\right.$ $\cdot s / m o l e ］ \quad g_{a} \_A$ ：葉面境界層コンダクタンス $\left[\mathrm{mole} / \mathrm{m}^{2} \cdot \mathrm{s}\right] \quad \mathrm{g}_{\mathrm{a} \_} \mathrm{B}$ : 葉面境界層コンダクタンス $[\mathrm{cm} / \mathrm{s}] \quad \mathrm{g}_{\mathrm{a}} \mathrm{C}$ : 葉面境界層コンダクタンス $\left[\mathrm{kg} / \mathrm{m}^{2} \cdot \mathrm{s}\right] \quad \mathrm{d}$ : 特性長 $=0.72 \times \mathrm{W}_{\max }[\mathrm{m}] （ \mathrm{~W}_{\max }$ ：葉の幅の最大值） $\mathrm{ch}: 0.06[-] \mathrm{u}$ : 風速 $[\mathrm{m} / \mathrm{s}] \quad \rho:$ 空気密度 $\left[\mathrm{kg} / \mathrm{m}^{3}\right] \quad \mathrm{k}$ : 坂本らの定数 19$)$

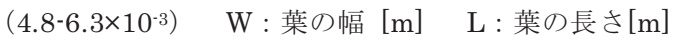

